se $\operatorname{sen} x \sin ^{2}$
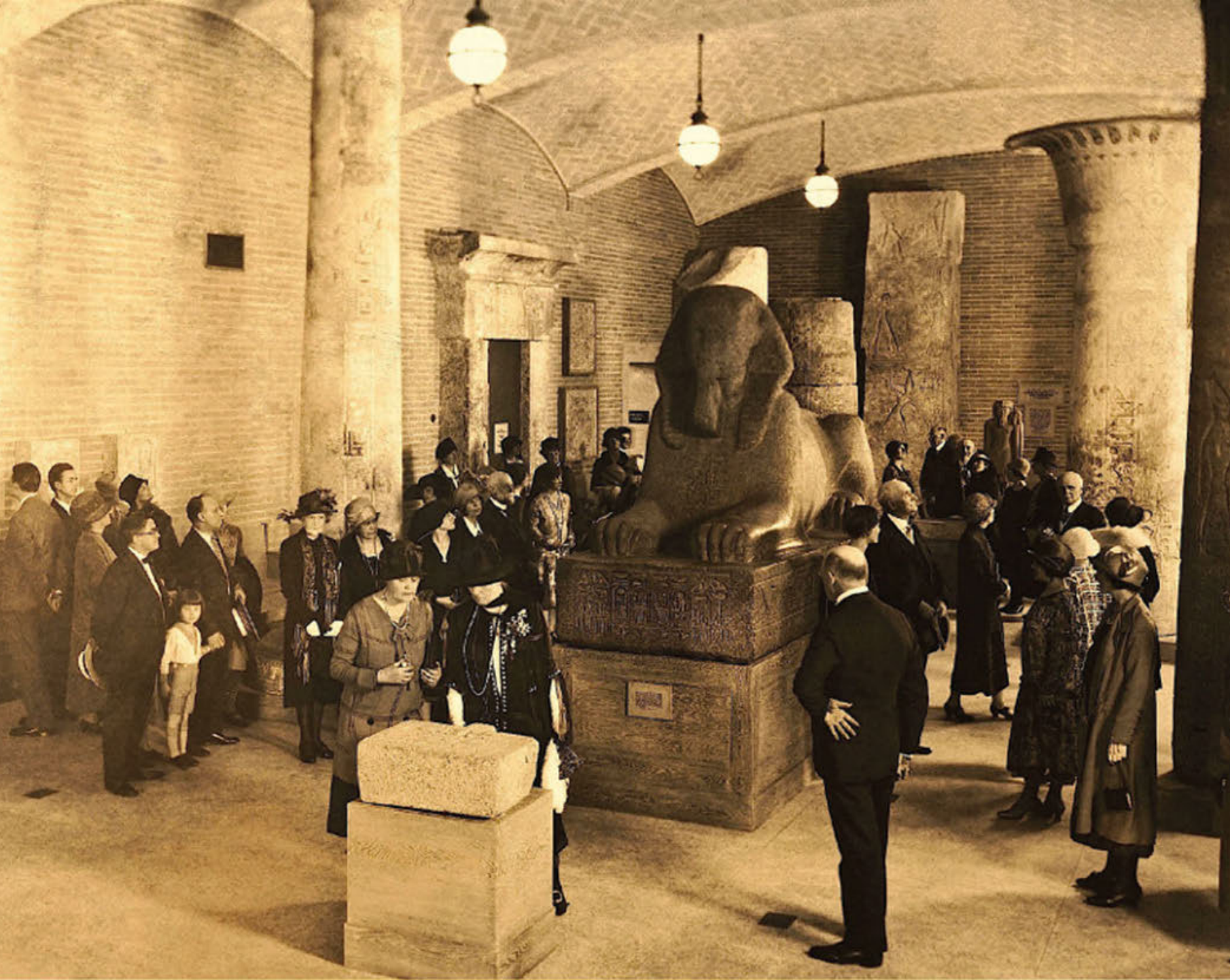

\title{
THE SPHINX
}

THAT TRAVELED TO

$$
\text { PH I LA D E L P H I A }
$$

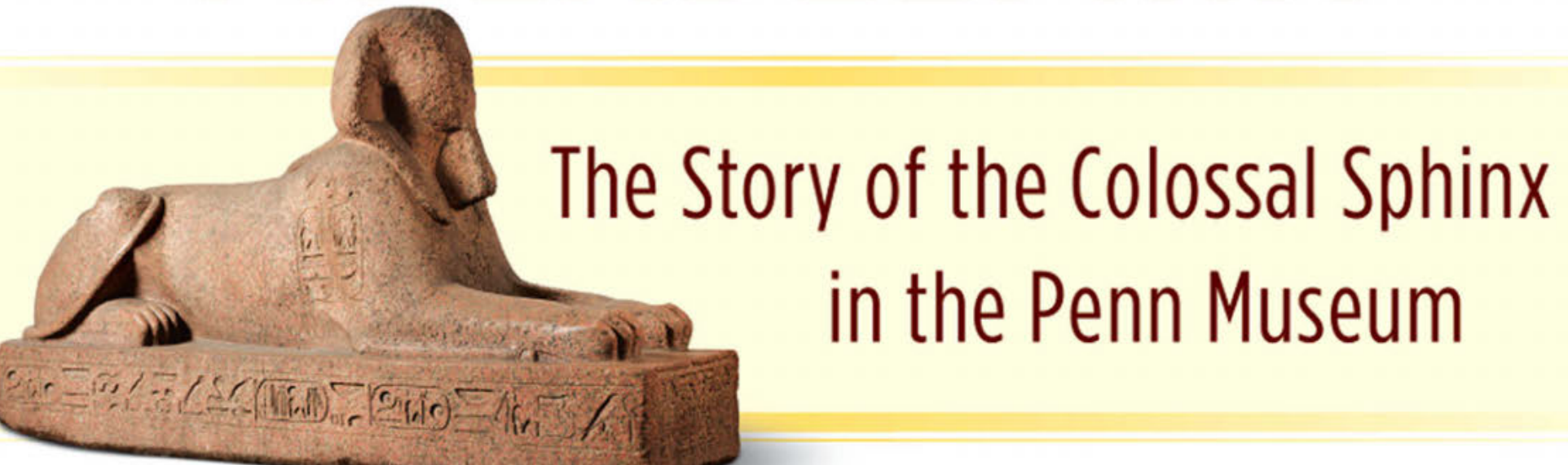

Josef Wegner and Jennifer Houser Wegner 


$$
\begin{aligned}
& \text { The Sphinx } \\
& \text { that Traveled } \\
& \text { to Philadelphia }
\end{aligned}
$$




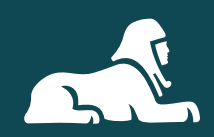

After years of waiting, it was before me at last. The great face was so sad, so earnest, so longing, so patient. There was a dignity not of earth in its mien, and in its countenance a benignity such as never any thing human wore. It was stone, but it seemed sentient. If ever image of stone thought, it was thinking. It was looking toward the verge of the landscape, yet looking at nothing-nothing but distance and vacancy. It was looking over and beyond every thing of the present, and far into the past. It was gazing out over the ocean of Time...

- Mark Twain, The Innocents Abroad (1869) 


\section{The Sphinx \\ that Traveled to \\ Philadelphia}

The Story of the Colossal Sphinx

in the Penn Museum

By Josef Wegner \& Jennifer Houser Wegner 
Wegner, Josef W. (Josef William), author.

The sphinx that traveled to Philadelphia : the story of the colossal sphinx in the Penn Museum / Josef Wegner and Jennifer Houser Wegner.

pages $\mathrm{cm}$

Includes bibliographical references.

ISBN 978-1-934536-76-6 (hard cover : alk. paper)

1. University of Pennsylvania. University Museum-History. 2. Sphinxes (Mythology) 3. Excavations (Archaeology) -EgyptMemphis (Extinct city) 4. Museums-Acquisitions-Pennsylvania-Philadelphia. 5. Memphis (Extinct city)-Antiquities.

6. Memphis (Extinct city)-Civilization. I. Wegner, Jennifer Houser, author. II. Title.

DT62.S7W44 2015

$932-\mathrm{dc} 23$

(C) 2015 University of Pennsylvania Museum of Archaeology and Anthropology

Philadelphia, PA 19104-6324

Published for the University of Pennsylvania Museum of Archaeology and Anthropology by the University of Pennsylvania Press.

All rights reserved. Published 2015.

Printed in People's Republic of China on acid-free paper. 
For Elizabeth Jean Walker, Friend of Egyptology and the Penn Museum 
